\title{
AFRICAN FEMINISMS: PARADIGMS, PROBLEMS AND PROSPECTS
}

\author{
FEMINISMOS AFRICANOS: PARADIGMAS, PROBLEMAS Y \\ PERSPECTIVAS
}

Author / Autor:

Rowland Chukwuemeka Amaefula Alex Ekwueme Federal University

Ndufu-Alike, Nigeria

emy4real2004@gmail.com

https://orcid.org/0000-0001-7012-2239

Submitted / Recibido: 03/11/2020

Accepted / Aceptado: 17/08/2020

To cite this article / Para citar este artículo: Amaefula, Rowland Chukwuemeka. «African Feminisms: Paradigms, Problems and Prospects». In Feminismo/s, 37 (January 2021): 289-305. https://doi.org/10.14198/ fem.2021.37.12

\section{Licence / Licencia:}

This work is licensed under a Creative Commons Attribution 4.0 International.

\section{(c) (1)}

(C) Rowland Chukwuemeka Amaefula

\section{Rowland Chukwuemeka AMAEFULA}

\begin{abstract}
African feminisms comprise the differing brands of equalist theories and efforts geared towards enhancing the condition of woman. However, the meaning and application of the word 'feminism' poses several problems for African women writers and critics many of whom distance themselves from the movement. Their indifference stems from the anti-men/anti-religion status accorded feminism in recent times. Thus, several women writers have sought to re-theorize feminism in a manner that fittingly captures their socio-cultural beliefs, leading to multiple feminisms in African literature. This study critically analyzes the mainstream theories of feminisms in Africa with a view to unravelling the contradictions inherent in the ongoing efforts at conceptualizing African feminisms. The paper further argues for workable ways of practicing African feminisms to serve practical benefits for African man and woman, and to also function as an appropriate tool for assessing works by literary writers in Nigeria in particular and Africa in general.
\end{abstract}

Keywords: Feminisms; Africana Womanism; Womanism; African Feminism and Patriarchy 


\section{Resumen}

Los feminismos africanos abarcan diferentes teorías y esfuerzos dirigidos hacia la mejora de la condición de las mujeres. Sin embargo, el significado y la aplicación de la palabra «feminismo» plantea diversos problemas para las escritoras y críticas africanas, muchas de las cuales se distancian del movimiento ante las etiquetas anti-hombres/anti-religión que se le ha otorgado al feminismo en los últimos tiempos. Así, varias escritoras han intentado volver a teorizar el feminismo de tal modo que permita integrar de forma adecuada sus creencias socioculturales, lo que ha llevado a múltiples feminismos en la literatura africana. Este estudio analiza de forma crítica las teorías dominantes de los feminismos en África con el fin de desenmascarar las contradicciones inherentes en los esfuerzos emprendidos para conceptualizar los feminismos africanos. Este trabajo también aboga por formas viables de practicar los feminismos africanos para beneficiar tanto a las mujeres como a los hombres africanos, de tal forma que constituya una herramienta apropiada para evaluar las obras literarias en Nigeria, en particular, y en África, en general.

Palabras clave: feminismos; Africana Womanism; Womanism; feminismo africano y patriarcado.

\section{INTRODUCTION TO AFRICAN FEMINISMS}

African feminisms encapsulate the differing brands of equalist theories and efforts geared towards enhancing the condition of the African woman. African feminists presuppose that man is privileged with patriarchal dividends at woman's expense. Thus, they make efforts towards reversing perceived injustices instituted against woman, across the ages. Right from the myth of Eden to modern times, the social constructions of masculine and feminine gender roles reinforce specific stereotypes: women epitomize passive purveyors of destruction for man and, indeed, humanity while men typify assertiveness and authoritarian dispositions that bolster their domination of women. This rigid demarcation of social roles misrepresents the varying temperaments of gender categories and tendentiously prescribes imbalanced roles for man and woman. The arrangement prompted the earliest feminist movement which cavilled the status quo and enunciated a monolithic approach to resolving issues that trouble women.

Feminism «seeks to understand the ways in which women are oppressed-socially, economically, politically and psychologically-in order

Feminismo/s 37, January 2021, 289-305 
to reduce, if not eliminate their oppression» (Bressler 144). Across its phases, the feminist movement has been marked by rebellion, beginning with the white woman's rejection of domination by her male counterpart. It is this mainstream feminism that Alice Walker revolts against, citing the white woman's negligence of the intersection between racism and femaleness which yields a double oppression for Afro-American women. In substantiation of this view, Elaine Showalter argues that the black woman, in relation to her white counterpart, is «the Other Woman, the silenced partner» who must equip herself with a voice against «the sexism of black literary history» and against «the racism of feminist literary history» (214).

Drawing from this background of double marginalization, Alice Walker theorizes on Womanism to empower the black woman. She explains the Womanist theory as follows:

Womanist 1. From womanish. (Opp. of «girlish», i.e., frivolous, irresponsible, not serious.) A black feminist or feminist of color. From the black folk expression of mothers to female children, «You acting womanish,» i.e., like a woman. Usually referring to outrageous, audacious, courageous or wilful behavior. Wanting to know more and in great depth than is considered «good» for one. Interested in grown-up doings. Acting grown up. Being grown up. Interchangeable with another black folk expression: «You trying to be grown.» Responsible. In charge. Serious.

2. A woman who loves other women, sexually and/or nonsexually (xi-xii).

Tracing the etymology of womanism from 'womanish', Walker constructs a new femininity, equating the liminal phase of becoming woman with being grown-up, serious and in-charge of her affairs. By capturing the rights of women of colour alongside the blacks' in her theory, Walker accommodates the interests of all non-white women to avoid the lacuna of exclusion of which she accuses the mainstream feminism.

Womanism would have sufficed for African feminists except for two factors: first, scholars widely disagree with Walker's Black Feminism, arguing that it «relates to African-American women in particular,» and «is extremely problematic as labels for the true Africana woman and invites much debate and controversy» (Hudson-Weems 18). Second, the lesbian thrust of the theory makes it repulsive to many African feminists due to widespread homophobia in most parts of the continent. This accounts for the ongoing 
proliferation of theories on African Feminisms. The rest of this article will be devoted to examining the various strands of feminisms in Africa, particularly Nigeria, and their deficiencies as well as suggestions on ways-out.

\section{TRENDS AND VARIETIES OF AFRICAN FEMINISMS: THE NIGERIAN EXAMPLE}

In this section, the idea of African Feminisms is examined from the perspective of equalist concepts and practices prevalent in Nigeria. Writers and critics of Nigerian origin are at the vanguard of (re-)constructing workable versions of mainstream feminism on the African continent. Be it Motherism, Snail-sense Feminism, Nego-feminism or African Womanism, majority of the strands constituting African Feminism were coined by Nigerians. The following paragraphs of this section explore the meaning and evolutionary phases of African Feminisms, beginning with the varying connotations associated with the feminist tag among women writers, theorists and critics mainly in Nigeria and elsewhere in Africa.

The meaning and application of the term feminism in Africa poses several problems for African women writers and critics, most of whom are inclined to approach the feminist theory with an elusiveness that bespeaks denial. These writers consciously dissociate themselves from the feminist movement, even though their works advance the goals of feminism. Their indifference perhaps arises from the misapprehensions that besiege feminism and its multiple nuances. «Feminism is often interpreted as being anti-male, anti-culture and anti-religion in its theoretical framework. It therefore becomes challenging for a woman writer who shares none of these ideologies» to take-on the feminist tag (Nkealah 133). For instance, some women writers such as Bessie Head, Mariama Ba and Buchi Emecheta openly detach themselves from feminism, causing Ogundipe-Leslie to explain their indifference towards the theory as follows:

Male ridicule, aggression and backlash have resulted in making women apologetic and have given the term 'feminist' a bad name. Yet nothing could be more feminist than the writings of these women writers in their concern for and deep understanding of the experiences and fate of women in society (64). 
In the estimation of the present writer, Ogundipe-Leslie's perspective above is not fully supported by research. These writers unequivocally point to the amorphous meanings associated with feminism and not the 'male ridicule and backlash' as the reason for their stance. Zaynab Akali, for example, laments that feminism rather «interferes with women's writing» (James 31). In the absence of a considerate understanding of these writers' fears, they are left with the choice of embracing feminism together with all its anti-social connotations or re-theorizing it in a manner that fittingly captures their socio-cultural beliefs. Thus, African women writers and critics have had to navigate through 'feminism', 'womanism', 'African Feminism' and 'Africana Womanism' in search of appropriate theories for the interpretation of their writings.

Chioma Filomena Steady seeks to reverse the western ideologies inherent in both Feminism and Womanism. She offers her theory of African Feminism to project the peculiarities of the African woman. According to her,

Regardless of one's position, the implications of the feminist movement for the black woman are complex... Several factors set the black woman apart as having a different order of priorities. She is oppressed not simply because of her sex but ostensibly because of her race and, for the majority, essentially because of their class. Women belong to different socio-economic groups and do not represent a universal category. Because the majority of black women are poor, there is likely to be some alienation from the middle-class aspect of the women's movement which perceives feminism as an attack on men rather than on a system which thrives on inequality (23-24).

Steady's theory is, however, dismissed by Hudson-Weems on account of nomenclature. The latter contends that,

in spite of the accuracy of Filomena Chioma Steady in The Black Woman Cross-Culturally in her astute assessment of the struggle and reality of Africana women, the name itself, African feminism, is problematic, as it naturally suggests an alignment with feminism, a concept that has been alien to the plight of Africana women from its inception (18-19).

Further, Hudson-Weems rejects Feminism, Womanism and African Feminism. In her view, Feminism is a white women's establishment instituted to protect their rights, and identifying with the movement is coterminous to subjecting blackness to white supremacy and sustained domination. Additionally, 
she debunks Womanism on the grounds of its lesbian thrust just as she emphasises the lacuna in African Feminism. Hudson-Weems believes that it contradicts the impossibility of blacks to be feminists-white women who combat their men to achieve equality. In presenting the theory of Africana Womanism as a viable alternative for Feminism, Womanism and African Feminism, Hudson-Weems contests African Feminism on two grounds: feminism, according to her, is not different from all other white establishments such as Communist Party and National Organization for Women (N.O.W.) which only legitimizes the interests of white people and perpetuates the subjugation of blacks in general. In addition, she states that

the Africana woman does not see the man as her primary enemy as does the White feminist, who is carrying out an age-old battle with her White male counterpart for subjugating her as his property. Africana men have never had the same institutionalized power to oppress Africana women as White men have had to oppress White women (25).

The point here is that Africana Womanism eschews the radical tendencies of feminism; inclinations that impel the segregation of women from men; and reversal of 'imaginary' subjugation of Africana woman by man. Indeed, an Africana man lacks the institutional power to subjugate an Africana woman just as she does not see him as her enemy. For instance, the presence of powerful warriors, priestesses and queens in traditional African societies nullifies the view that women completely existed on the fringes, suffering oppression in the hands of men. From a historical standpoint, Ifi Amadiume explains that, in Nigerian pre-colonial society, women were not completely estranged; the Igbo traditional society, for example, ran «a flexible gender construction» (15).

However, debunking the claim that sexism hardly existed in most traditional African societies and Africans neither equated men with superiority and women with inferiority, Ezeigbo argues that, «It is rather more correct to say that the extent of devaluation of women varied from one society to another. For example, women appeared to have had more rights and to have been accorded more recognition in Yoruba land than they were in traditional Igbo society» (Gender Issues xv). Ezeigbo's opinion is premised on the inheritance rights granted women in Yoruba land. Unlike her Igbo counterpart, a Yoruba woman inherits land from her father. In many parts of northern Nigeria, 
the prevalence of Islam which subordinates woman to man disinherits and reduces her to the appendage of man in many ways. This view is oblivious of recorded instances of women's heroic acts in Nigeria. For instance, in Emeka Nwabueze's The Dragon's Funeral-a dramatic re-creation of the 1929 Aba Women's riot in colonial Nigeria, women of Osisioma Ngwa plan, engage in and execute feats that rescue the womenfolk and, indeed, the entire community from mass taxation by colonial administrators. The success attained by women is traceable to their conscious identification of whom/what the problem/enemy is. Adaugo explains as follows:

Adaugo: Women of my ancestral land, there is dust in the air. Evil men have enveloped our land. The name of that evil, that dust is government. We have heard different rumours about what government is doing and even what it intends to do. Our husbands have heard it, our children have heard it, even the trees of our land have heard it. The serene atmosphere of this village will soon be disrupted by the strangers in our midst who call themselves government (Nwabueze 18; my emphasis).

The women's recognition of their enemy gives a sense of direction to their eventual steps. In addition, it is apparent in the excerpt that the women are mindful of disrupting peace in the village. Thus, they single out their problem-taxation-and tackle it to the end. This drama lends credence to the existence of multiple gender performances by women in Nigeria and indeed Africa. Rooted in cultural variations among the Hausa, Igbo and Yoruba-the dominant ethnic groups in Nigeria-the different ways of doing the feminine gender lead to sundry perspectives on the woman question.

The plurality of African feminisms signposts the cultural differences among women, including the various dynamics that constitute their lived experiences; patriarchal tenets; and a recognition of the need for relevant African feminist approaches that can give women a voice. Ogundipe-Leslie disagrees with the view that African women do not need liberation or feminism because they have never been in bondage (542). In reinforcing her opinion that African women are oppressed, she explains the six mountains on the back of an African woman and wonders why, in Africa, «Man is always superior to woman, [and] boys should go to school and girls should only go when they can, when there is money to «waste» and no work to be done at home or in the farms and markets?» (548). She therefore proposes STIWA—an acronym 
for Social Transformation Including Women in Africa-as a replacement for feminism, in order to «bypass the combative discourses that ensue whenever one raises the issue of feminism in Africa» (549). This new acronym, in the view of Ogundipe-Leslie, would douse the tension generated each time feminism is mentioned; men and women would naturally accept the inclusion of women in the social transformation of Africa. Similar to Ogundipe-Leslie's STIWANISM which advocates for women's co-partnership in the transformation of Africa are Chikwenye Ogunyemi's Black Womanism and African Womanism, Catherine Acholonu's Motherism, Obioma Nnaemeka's NegoFeminism and Chioma Opara's Femalism.

Femalism opposes Simone de Beauvoir's revulsion of nature, highlighting the female body as an essential biological site «foregrounded as a transcendent mechanism of constructive and generative nature» (Opara, «On the African» 190). Comparing the scarred female body to the African continent lacerated by poverty, war and hunger, Opara's femalist thought focalises the woman's body-which she likens to mother earth, making a poignant claim on the relationship between the liberation of African women and Africa at large. Femalism advocates for the creation of awareness on feminism without greatly opposing man; he is rather tolerated, on compassionate grounds, as a partner in progress, as long as he does not constitute a barrier to women's self-actualization. This theoretical prescription of gender roles tends to suggest a denigration of man, and consequently portrays feminist theorists as individuals who do not truly desire gender equality but a role-reversal of the alleged oppression against them. The femalist ideology is similar to Ogunyemi's Womanism which stresses black harmony as follows:

Womanism is black-centred. It is accommodationist. It wants meaningful union [sic] between black women and black men and black children, and will see to it that men will change from their sexist stand. This ideological position explains why women writers do not end their plots with feminist victories (5).

Womanism is definitely practicable just as womanists desire unity among black men, women and children. It ought to have been adopted as a standard prescription of gender behaviour and goals for the black Africans, if not for the endless theoretical constructions of African feminist theorists. Catherine Acholonu theorizes on Motherism which, according to her, is «a 
multi-dimensional theory which involves the dynamics of ordering, re-ordering, creating structures, building and rebuilding in cooperation with «mother nature» at all levels of human endeavour» (110-111). The thrust of this theory is the promotion of mutual love, tolerance and defence of family values, without violence and allied hostilities between man and woman.

One wonders how Motherism is different from Ogunyemi's Womanism, considering that both concepts preach the cooperation of both men and women and the defence of «black roots» and family values (Ogunyemi 6). Arguing that the only importance of the Motherist theory is «to add to our feminist vocabulary», Nnolim submits that African Feminisms are a house divided against itself. His point is based on the metaphor of mayhem arising from African feminists' interest in creating their personal theories instead of unifying efforts to achieving a definite practicable concept. While seemingly corroborating the need to cease proliferation of theories, Akachi Ezeigbo argues that

African feminism and African Womanism are one and the same thing; and we do not see any significant difference. In Carole Boyce Davies' summary of African feminism, she refers to its recognition of a common struggle with African men against European/American exploitation; its respect for the African woman's status as mother; its validation of the virtues of self-reliance and the penchant to cooperative work but rejection of the overburdening exploitation of women by patriarchy. These attributes are equally identified with African Womanism («Cyprian Ekwensi» 139).

In defence of the multiple theories of African feminism however, Chioma Opara states that,

Nnolim's apprehension may be justifiable for he, in his capacity as a vocal gynandrist, has in no small measure identified with the female cause, albeit moralistically. But it is rather premature to draw negative conclusions at this early stage of theoretical development in African feminism. There can be no doubt that the variants of African feminism, much younger than the theory of Western antecedents are in spite of few teething troubles developing gradually. In fact, the different currents appear to be flourishing root and branch notwithstanding that cultural drawbacks and socio-political upheavals have beset the beleaguered continent («Making Hay» 4).

Therefore, be it feminism, womanism, gynism or femalism, the binding thread of female playwrights' schools of thought is the improvement of the woman's

Feminismo/s 37, January 2021, 289-305 
condition. As Eboh puts it, «The four currents have one and the same theme, but different perspectives. They have one philosophy which is varying existential backgrounds and lived experiences. The root of inequality between the two genders and the long but sporadic struggle is the point...» (12). The point being made here is that, in proffering answers to why the feminine gender roles are not considered equal with the masculine roles, different scholars have adopted different schools of thought and methodologies. These theories are certainly African derivatives of mainstream feminism, indicative of the fact that feminism means different things to different people depending on race, culture and historical experiences. In Nigeria, many people understand feminism to simply mean women's struggle to gain equality with men, or to obtain access to positions of power.

Considering the discrepancy in the experiences of the white woman and black woman, Eboh asserts that «the black woman activist in the African continent is a gynist while the black woman in the African Diaspora is a womanist» (13). Further, Eboh explains that their dissatisfaction with the appendage status accorded women by the usual practice of having to name and define her always «in terms of man», gave rise to the term 'gynist' (13). She illustrates that $"[\ldots]$ in womanism, for instance, there is man and in femalism, male is there too. This has necessitated the coinage of the terminology, gynism, otherwise, we do not have much against the philosophy of womanism as well as Chioma Opara's femalism...» (Eboh 14).

Another African derivative of feminism is the Snail-Sense Feminism. Propounded by Adimora-Ezeigbo, the theory holds that women should behave like the snail which does not confront any obstacle but negotiates its way out. It is related to Obioma Nnaemeka's Nego-Feminism which expresses: «First, ...feminism of negotiation; second, nego-feminism stands for «no ego» feminism» (Nnaemeka 377-78). Adimora-Ezeigbo's Snail-Sense feminism urges women not to see virtues they share with the snail-wisdom, sensitivity, resilience and doggedness or determination- «as a weakness... rather they should be seen as a way of strategizing to complement the man and join forces with him to develop the society for the benefit of all» (Adimora-Ezeigbo 29). The Snail-Sense Feminism, a theory that emphasizes individualism and complementarity of the sexes, states that, 
The individual must empower herself before she can empower others. She must stand before she can help other people stand. The pursuit of individual success and development is central to Snail-Sense Feminism. The woman should not just accommodate others, but ensure that she achieves recognition for herself because self-preservation and self-actualization are crucial to a woman's success in life. And if she succeeds, the success of the family or the community follows naturally (Adimora-Ezeigbo 35).

Apparently, individualism - an aspect of western feminism, and complementarity-a concept in African Womanism have combined to produce what Adimora-Ezeigbo refers to as 'Situated Feminism'. This concept of Situated Feminism, in Adimora-Ezeigbo's view, would enable women in Africa to

Survive the harsh patriarchal culture. Chikwenye Ogunyemi refers to this attitude of women in our culture as the four Cs: Collaboration, Conciliation, Cooperation and Complementarity. Obioma Nnaemeka refers to it as 'NegoFeminism' which has given rise to her theory Nego-Feminism, that actually means feminism of negotiation (Obafemi 29-30).

The foregoing reveals an abundance of theories that describe and prescribe the socially accepted roles of men and especially women in Africa. Even though the present researcher privileges the harmonization of efforts towards creating a practicable theory on African feminism, it is remarkable to note that women writers and critics in the continent have continued to make tremendous efforts in seeking ways of understanding and enhancing their conditions in Africa which is a stronghold of patriarchal tenets. It is possible that several women writers and critics are still working on more theories to properly conceptualize African feminisms. This explains the position of this article on the need to unify theoretical efforts and emphasize practice.

\section{PROSPECTS OF AFRICAN FEMINISMS: THE DRAMA EXPERIENCE}

The belief that men are homogenously oppressive of women-as captured in the various theories above-gainsays the existence of male feminists as well as refutes any claim to multiple masculinities. Interestingly, this conviction projects all men as a primary enemy of women who must be re-oriented, tolerated or even fought to a standstill, causing African feminisms to remain remote to many African men and even seen as a war against them and not the system of patriarchy which enfeebles women. The point is, while the emasculation

Feminismo/s 37, January 2021, 289-305 
of women may not be a common trait in all men, the former's complicity in instituting masculine hegemony cannot be denied. Even proponents of African feminisms subscribe to this view but quickly excuse women's role in self-oppression as a consequence of sustained systematic «intimidation» and brainwash by the patriarchal society (Ogundipe-Leslie 64). According to Chimamanda Ngozi Adichie, «...I have always said that sometimes it is the women themselves who have been brainwashed to hold themselves down, and the only way we can get out of this is feminism» (qtd. in Akubuiro 4).

This defence pales into insignificance when contemplated against the background that African feminist writers unconsciously assign seemingly denigrating gender roles to female characters in their fiction and especially plays. In demonstrating their variants of African feminist theories in drama, for example, feminist playwrights show different ways women should combat men by creating female characters who leverage coition and domestic chores as their sole bargaining power. This practice dilutes the woman's intellectual worth and delineates her as docile and incapable of other salutary purposes. For example, in Nigerian plays such as Stella Oyedepo's The Rebellion of the Bumpy-Chested, Julie Okoh's Edewede, J. P. Clark's The Wives' Revolt among others, women attain empowerment by depriving their husbands of sex and domestic chores at home. In J. P. Clark's The Wives' Revolt in particular, Koko, Okoro's wife, leads other women of Erhuwaren community on exile in protest against unfair sharing formula and obnoxious laws men institute against women. These women punish men with the absence of coition and domestic chores and never return home until they (men) reverse the discriminatory formula and law.

Evidently, Koko's brand of feminism is built on bitterness, rancour and acrimony. She propagates and celebrates women who view every man as a potential enemy as well as valorizes the downfall of marriages. Her abdication of oath-based matrimonial responsibilities characteristic of decent marriages portrays women in the play who tread the path of peace and reconciliation in nuptial unions as timid, weak and completely brainwashed by the prevailing patriarchal system. By leading women to part with their families, Koko can be safely described as a woman who is intolerant of any marital hiccup; a preacher of separation and divorce; and a manipulator who attributes bravery to women that publicly bash their husbands at the slightest

Feminismo/s 37, January 2021, 289-305 
marital slip. Furthermore, the image-implication of Koko's strategy of punishing men through women's exodus from Erhuwaren, is manifold. First, it portrays women as people whose sole essence ends in domestic chores and copulation. This is because Koko is not empowered with any specific skill or training; she offers no unique service which the Erhuwaren community would continue to seek, in her absence. Hence, her resort to biological endowments. Expectedly, Okoro challenges her, thus:

Okoro: But what other thing can (women) do? Ban us from your beds? That won't work either, for we'll only invite the women on the road into town by popular demand... (Clark 11).

Without holding brief for Okoro who is swollen with unrefined masculine arrogance, the present writer emphasises that, while the emasculation of women may not be a common trait in all men, the former's complicity in reinforcing masculine hegemony cannot be gainsaid. By fleeing to the disease-stricken Eyara, women of Erhuwaren in the play have proven to be unable to withstand their male counterpart in any intellectual debate. Absconding is not only un-African but also cowardly and extremely radical. Fleeing from Erhuwaren to Eyara, instead of staying back to make a case against perceived injustice against them, is the women's tacit concession of hegemony to men. One wonders if women would need to repeatedly abscond from homes in order to resolve every dispute affecting them. It would have been more courageous for women to remain in Erhuwaren and form women leagues that can tackle the issues affecting them, within established social structures. All these would have been possible if Koko was empowered and could thus empower other women. In the absence of a refined leader who should refine other women, she leads them to an aggressive revolt that attains only a provisional success.

This technique unwittingly projects the celebration of conditional victory of woman over man which Chimamanda Ngozi Adichie describes as Feminism Lite. She warns women to

[b] eware the danger of what I call Feminism Lite. It is the idea of conditional female equality. Please reject this entirely. It is a hollow, appeasing and bankrupt idea. Being a feminist is like being pregnant. You either are or you are not. You either believe in the full equality of men and women or you do not. Feminism Lite uses analogies like 'he is the head and you are the neck'. 
Or 'he is driving but you are in the front seat'. More troubling is the idea, in Feminism Lite, that men are naturally superior but should be expected to 'treat women well'. No. No. No. There must be more than male benevolence as the basis for a woman's well-being. Feminism Lite uses the language of 'allowing' (Dear Ijeawele 10).

Based on this understanding, it is apparent that the brand of feminism worked out by many writers who project women in African literature does not only promote conditional liberations but additionally flout the many conventions that constitute the amorphous field termed African feminisms.

The unstructured nature of African feminisms stems from its inherent contradictions. For instance, one wonders what discernible difference exists between Nego-Feminism and Snail-Sense Feminism, considering that both theories foreground negotiation as the woman's basic tool in a sexist society. Chikwenye Ogunyemi's Womanism, Chioma Opara's Femalism and Catherine Acholonu's Motherism focalize co-partnerships of men and women; therefore, they do not differ much in meaning but help to increase the lexicon of African feminisms. Indeed, the absence of harmonious thoughts that drive progress have made African feminisms to be conflicting in meaning and too elitist to bear any direct impact on the lives of ordinary women outside the academia. In the Nigerian setting, for instance, there exist many women who are ignorant of these multiple theories and how they could help them understand and enhance their living conditions in a patriarchal system.

There is need to unify efforts in the execution of African feminisms. Mass re-orientation of young women and men is key to moulding future feminists (Adichie, We Should 12; Amaefula 9). More importantly, men have to be accommodated in addressing issues that affect women negatively. That is, African feminists should strive hard to emphasize patriarchy and not man as the source of oppression against women. This would gradually reverse the propaganda that all feminists are frustrated women who are anti-men, anti-religion and anti-culture. More so, the metaphysical consequences built around traditional practices considered harmful to women should be demystified as creations of patriarchy which have hardened into traditions over time. They should be explained with evidence, especially to young people, as self-serving structures sustaining sexism. In addition, there must be deliberate efforts towards setting up period-specific agenda on how to dismantle the reign

Feminismo/s 37, January 2021, 289-305 
of patriarchy. This can only be achieved when there is unity of purpose. By setting timelines to specific agenda, African feminists would be able to take stock and assess their achievements over a period of time.

\section{CONCLUSION}

This study has argued that lack of harmonious, progressive thoughts on the strategies of gaining gender equality is the bane of African feminisms. The chase for status has engendered some women writers and critics to propound theories which do not quite differ from the existing ones they jettison. Consequently, the rapidly emerging theories gain the day at the expense of women's liberation from the patriarchal grip. Having attempted a holistic analysis of the prominent theories that make up African feminisms, this paper calls for the reformation of African feminists to be more remedial, proactive and practically responsive to the concerns of humanity. While some leading scholars of African feminisms pursue a display of erudition and sophistication by proliferating theories, some young African feminists-starved of leadership_mistake feminism for the emission of anti-men ringtones and convocation of schemes to collapse marital institutions. Their strategy is a sweeping attack on all men as (potential) oppressors.

On social media and in literary texts, many young African feminists brand women (such as Adaugo in Emeka Nwabueze's The Dragon's Funeral) who, in the course of feminist agitation, try to make marriages work as weak, faint-hearted and brainwashed. The ascription of bravery to women who trumpet divorce and absconding from home for every challenge in marriage or perceived injustice against them, can increase the cases of divorce witnessed in Nigeria today. It is a recipe for amplifying the number of broken homes and single mothers in the country many of whom echo divisive chants and deride men in public, as part of the praxis of African feminisms. The latter-day scholars of African feminisms should prioritize a period-specific goal to guide the agitation. While acknowledging that issues affecting women are not a monolith, the need for a roadmap cannot be denied. It would help channel all the African feminists' efforts towards a particular main objective and different minor aims within the specified period. In the absence of unity of purpose, African feminisms would continue to have many more theories 
countering existing ones as well as emergency feminists who are not rooted in the knowledge and vision of the movement.

\section{REFERENCES}

Acholonu, Catherine. Motherism: The Afrocentric Alternative to Feminism, Let's Humanita-rian Project, Women in Environmental Development Series. Vol. 3. Owerri, Nigeria: Afa Publications, 1995.

Adichie, Chimamanda Ngozi. Dear Ijeawele or a Feminist Manifesto in Fifteen Suggestions. London: 4th Estate, 2017.

Adichie, Chimamanda Ngozi. We Should All Be Feminists. New York: Vintage Books, 2014.

Adimora-Ezeigbo, Akachi. Snail-Sense Feminism: Building on an Indigenous Model. Lagos: Wealthsmith, 2012.

Akubuiro, Henry. «I've Soft Spot for a Reserved Intelligent Guy - Chimamanda Adichie». 14 Jan.2007. https://www.naijarules.com/threads/i\%E2\%80\%99vesoft-spot-for-a-reserved-intelligent-guy-chimamanda-adichie.20587/. 7 Dec. 2016.

Amadiume, Ifi. Male Daughters, Female Husbands: Gender and Sex in an African Society. London: Zed Books, 1987.

Amaefula, Rowland Chukwuemeka. «Deleting the Silent Space of Women: Feminism and Voice Construction in Zimbabwean Drama». African Female Playwrights: A Study of Matter and Manner. Ed. Emeka Nwabueze. Enugu: ABIC, 2016. 21-33.

Bressler, Charles. Feminist Literary Theory: An Introduction to Theory and Practice. New York: Prentice Hall, 2007.

Clark, John Pepper. The Wives' Revolt. Ibadan: Ibadan UP, 1991.

Eboh, Marie Pauline. «Aetiology of Feminist, Womanist, Femalist and Gynist Philosophy». Beyond the Marginal Land: Gender Perspectives in African Writing. Ed. Chioma Opara. Port Harcourt: Belpot, 1999. 13-23.

Ezeigbo, T. Akachi. «Cyprian Ekwensi's Survive The Peace as a Critique of War and Patriarchy». Beyond the Marginal Land: Gender Perspectives in African Writing. Ed. Chioma Opara. Port Harcourt: Belpot, 1999. 137-150.

Ezeigbo, T. Akachi. Gender Issues in Nigeria: A Feminine Perspective. Lagos: Vista, 1996.

Hudson-Weems, Clenora. Africana Womanism: Reclaiming Ourselves. Troy MI: Bedford, 1993. 
James, Adeola. In their own Voices: African Women Writers Talk. London: James Currey, 1990.

Nkealah, Naomi N. «Conceptualizing Feminism(s) in Africa: The Challenges Facing Women Writers and Critics». English Academy Review: Southern African Journals 23.1 (2007): 133-141.

Nnaemeka, Obioma. «Nego-Feminism: Theorizing, Practicing, and Pruning Africa's Way». Signs 29.2 (2014): 357-85.

Nnolim, Charles. «African Feminism: The Scandalous Path». Beyond the Marginal Land: Gender Perspectives in African Writing. Ed. Chioma Opara. Port Harcourt: Belpot, 1999. 51-63.

Nwabueze, Emeka. The Dragon's Funeral. Enugu: ABIC, 2005.

Obafemi, Olu. «My Snail-Sense Feminist Theory Accommodates the Menfolk-Interview with Akachi Adimora-Ezeigbo». Nigerian Literature Today: A Journal of Contemporary Nigerian Writing 1 (n.d.): 2-18.

Ogundipe-Leslie, Molara. Recreating Ourselves: African Women and Critical Transformations. Trenton N.J.: Africa World Press, 1994.

Ogunyemi, Chikwenye Okonjo. «Womanism: The Dynamics of the Contemporary Black Female Novel in English». Signs 11.1 (1985): 68-69.

Opara, Chioma. «Making Hay on Sunny Grounds». Beyond the Marginal Land:

Gender Perspectives in African Writing. Ed. Chioma Opara. Port Harcourt: Belpot, 1999. 1-11.

Opara, Chioma. «On the African Concept of Transcendence: Conflating Nature, Nurture and Transcendence». Melintas 21.2 (2005): 189-200.

Showalter, Elaine. «A Criticism of Our Own. Autonomy and Assimilation in Afro-American and Feminist Literary Theory». Feminisms: An Anthology of Literary Theory and Criticism. Ed. Robyn R. Ward and Diane Price Herndl. New Jersey: Rutgers University Press, 1997. 213-233.

Steady, Filomena Chioma. The Black Woman Cross-Culturally. Cambridge, Mass.: Schenkman Publishers, 1981.

Walker, Alice. In Search of Our Mothers' Gardens: Womanist Prose by Alice Walker. New York: Harcourt Brace Jovanovich, 1984. 